\title{
RECEPCJA ESTETYCZNA POEZJI KONKRETNEJ NA LEKCJI JEZZYKA OBCEGO
}

\author{
KATARZYNA MEINEL
}

\begin{abstract}
The subject of the article is the aesthetic reception of concrete poetry and the possibility of its use in foreign language classes. Reception aesthetics concentrates on the reception of the work and not its production. Concrete poetry works on sight and hearing, combines decoding of letters with visual perception and creates special opportunities for aesthetic reception in foreign language classes. The article draws attention to the phenomenon of text communication. The historical background and the first attempts to experiment with concrete poetry are discussed. Works of concrete poetry bring together aesthetics and didactics, which justifies their use in class. The functions and objectives of working with concrete poetry in the lesson are discussed and examples of works included in textbooks and examples of lesson scenarios are given.
\end{abstract}

Key words: aesthetic reception, concrete poetry, reception aesthetics, reception of the work, autocommunication, text, functions and goals of working with concrete poetry in the lesson

\section{Recepcja estetyczna jako estetyka recepcji}

Estetyka jako jedna $\mathrm{z}$ wartości wchodzi w skład wielu dyscyplin naukowych. „Wartość estetyczna, jaką jest piękno powstaje w określonej sytuacji i nie może istnieć poza nią. [...] Aczkolwiek sytuacja estetyczna powstaje wtedy, gdy człowiek ujmuje rzeczy z pewnego szczególnego punktu widzenia - ów punkt widzenia „narzucony" jest przez zestawienie własności i struktur rzeczy" (Gołaszewska, 1984: 76). W ten sposób Maria Gołaszewska opisuje estetykę jako naukę zajmującą się tzw. sytuacją, w ramy której ujmowani są: artysta (jako twórca), proces twórczy, dzieło sztuki, odbiorca, proces percepcji sztuki oraz wartości estetyczne.

Jest to jedno z możliwych ujęć istotnego tu zagadnienia estetyki, intuicyjnie, również w znaczeniu potocznym, kojarzonego ze sztuką i pięknem, jednak dzięki 
temu skojarzeniu nie będąc ostatecznie zdefiniowanym, gdyż: przedmiot zainteresowań estetyki wychodzi [...] poza dziedzinę sztuki, a równocześnie obejmuje nie całą tę dziedzinę. Estetyka bowiem z jednej strony zajmuje się także innymi niż artystyczne wytworami pracy ludzkiej oraz zjawiskami natury o tyle, o ile mogą być one źródłem doznań estetycznych, z drugiej zaś strony pomija to wszystko, co w sferze sztuki nie daje się sprowadzić do fenomenów estetycznych (Głowiński i. in., 2002: 141). Piękno nie jest bytem samym w sobie, lecz powstaje w pewnej relacji do podmiotu, na co słusznie zwraca uwagę Gołaszewska. Oczywiście można w różnoraki sposób opisywać estetykę w odniesieniu do artysty / twórcy, jak i odbiorcy (widza, słuchacza, czytelnika). Z dydaktycznego punktu widzenia szczególnie przydatnymi koncepcjami estetycznymi są te, które ujmują powstawanie wartości estetycznej (o której mowa była na początku) w relacji dzieła sztuki z odbiorcą, a nie z twórcą, bo przecież w warunkach instytucjonalnych (= w szkole) nauczyciel jest tym, który może skonfrontować odbiorcę z dziełem sztuki. Twórca (reżyser, kompozytor, pisarz, malarz) w określonych warunkach mogą być włączeni do procesu dydaktycznego, ale nie są konieczni, aby doszło do doświadczenia estetycznego. Chodziłoby tu raczej o wartość poznawczą niż estetyczną, a celujemy raczej w tę drugą.

Koncepcją, która punkt ciężkości powstania wartości estetycznej przenosi z relacji artysta - dzieło na relację dzieło - odbiorca jest tzw. estetyka recepcji, koncepcja badań literackich stworzona przede wszystkim przez Wolfganga Isera oraz Hansa Roberta Jaussa, określana również jako poetyka odbioru lub socjologia literatury. Estetyka recepcji koncentruje się wokół odbioru dzieła a nie jego wytwarzania, dotyczy to zarówno struktury utworów, jak również procesu historycznoliterackiego. Główni przedstawiciele estetyki recepcji, wspomniani już Jauss oraz Iser, ale też Harald Weinrich, reprezentowali różne tradycje naukowe łącząc kilka dziedzin w jeden kierunek nauki o literaturze, który wypracował wiele kategorii badawczych (Głowiński i in., 2002: 142). Taki interakcyjny wymiar literatury - na co wskazują Kaniewska i Legeżyńska (2003: 56) - interesował również już wcześniej Michaiła Bachtina, który w swoich badaniach dowodził roli żywych ocen społecznych determinujących materiał poezji znacznie bardziej niż zbiór lingwistycznych możliwości. Natomiast Stefan Żółkiewski, którego przedmiotem zainteresowań była socjologia literatury, różnicuje wśród odbiorców różne obiegi społeczne literatury w zależności od ich możliwości odbioru, tj. wysokoartystyczne i popularne. Złożona konstrukcja dzieł literackich stwarza czytelnikom okazję do odbioru na każdym z poziomów ich organizacji (Kaniewska, Legeżyńska, 2003: 54-55). Sam Hans Robert Jauss ową elastyczność dzieła literackiego definiował w sposób następujący:

Dzieło literackie nie jest przedmiotem samym w sobie, który każdemu odbiorcy w każdym czasie ukazuje się tak samo. Nie jest pomnikiem, który monologicznie objawia swą ponadczasową istotę. Jest raczej jak partytura nastawiona na wciąż ponawiany rezonans odczytania, które wyzwala tekst z materii słowa i nadaje mu aktualne istnienie (Jauss, 1999: 143-144). 
Rolę czasu, w jakim osadzony jest odbiorca, podkreśla również Weinrich zwracając uwagę na możliwość określenia kręgów czytelniczych danej epoki i przypisania im charakterystycznych cech (Kaniewska, Legeżyńska, 2003: 57).

Estetyka recepcji, koncentrująca się wokół odbioru dzieł literackich przez czytelnika, uwzględniająca zarówno epokę (jako czas odbioru), środowisko, z którego wywodzi się odbiorca jak również jego osobiste predyspozycje poszerza możliwości interpretacji utworów.

Stanley Fish, mówiąc o response theory, podkreśla, że zamiast kierować uwagę na to, czym tekst jest (,what the poem is") należy się zastanowić jak on oddziaływuje na czytelnika (,what the poem does”). Rzeczywistość tworzona jest nie przez sam tekst, lecz przez reakcję czytelnika: „der Tekst existiert nicht wie ein Gegenstand an sich, er wird est zum Text durch den Leser” (,tekst nie egzystuje jako przedmiot sam w sobie, on staje się tekstem dopiero dzięki czytelnikowi”) (Wicke, 2004: 361) ${ }^{1}$.

Ważnym wydaje się być zatem uwzględnienie czytelnika i jego doświadczeń, które uzasadnia wykorzystanie tekstu literackiego na zajęciach z języka obcego.

Jeżeli w powyższym mamy na myśli recepcję estetyczną, to rozumiemy ją również jako estetykę recepcji - tzn. uczynienie z podmiotu (ucznia jako czytelnika oraz odbiorcy) instancji decydowania o sposobie rozumienia tekstu. Zostało to dostrzeżone w różnych koncepcjach dydaktyki nauczania języka niemieckiego jako obcego (tzw. $D a F$ ) już w latach 80. XX wieku (Lothar Bredella, Bernd Kast, Dietrich Krusche). Chodzi tu też o to, że poezja konkretna - która będzie przedmiotem dalszych rozważań, oprócz stosunkowo jednoznacznego pola recepcji, sugerowanego przez element graficzny i wizualny (elementy te ułatwiają recepcję), pozostawia jak zresztą każdy tekst literacki - dużą swobodę interpretacyjną czytelnikowi, a to może wręcz estetyczne doznania powstające przy odbiorze tekstu w sposób szczególny wspierać.

Poezja konkretna jako bardzo specyficzny gatunek literatury, zdaje się stwarzać szczególne możliwości recepcji estetycznej na zajęciach z języka obcego, działając na zmysł wzroku i słuchu. Należy przy tym zaznaczyć, że mówienie o oddziaływaniu na zmysł wzroku zawiera w sobie przynajmniej dwa tryby recepcji: pierwszy wynikający ze zwykłego dekodowania liter (jak w procesie czytania), a drugi z percepcji stricte wizualnej. Jak twierdzi Sabine Gross (1994: 74) - określając obydwa tryby recepcji jako „modusy znaczeniowe / sygnifikacyjne” (,Signifikationsmodi”) doznanie estetyczne wynika właśnie ze specyficznego powiązania obydwu modusów. Dziać się ma to również wtedy, gdy informacja zostaje zaserwowana podwójnie - jeden raz w modusie zwykłego dekodowania liter i wyrazów, a drugi w postaci wizualnej.

Radość wynika z podwójnego postrzegania (podwójnej recepcji): odpowiednik nie jest jedynie nadmiernym zdeterminowaniem (Überdetermination), ale dla czytelników / czy-

\footnotetext{
${ }^{1}$ Wszelkie tłumaczenia, o ile nie zaznaczono inaczej, pochodzą o autorki K.M.
} 
telniczek rozkoszą z ekscesu, przez sposób w jaki pismo i obraz się nakładają, a forma ikoniczna oraz leksykalna ze sobą korespondują. We wzajemnym oddziaływaniu dwóch heterogenicznych źródeł informacji napięcie różności nawet wtedy nie ulega całkowitej eliminacji, gdy przekazana informacja może być postrzegana jako identyczna (Gross, 1994: 74).

Istnieje wiele tekstów zaskakujących czytelnika swoją formą lub kierunkiem czytania (dając również możliwość odczytania w wielu kierunkach równocześnie). Celem poezji konkretnej jest zniesienie impulsu linearnego czyli pozbawienie czytania linearności. To, co na pierwszy rzut oka wygląda na rezygnacje ze składni, z połączeń zdań, służy stworzeniu miejsca dla wielowymiarowej przestrzeni. Pojawiające się po sobie słowa nie tworzą „łańcucha tekstu” (,,Textkette”) lecz ,powierzchnię tekstu” (,,Textfläche”). Teksty, w których zestawione są ze sobą słowa, tworzą ,płaszczyzny znaczeniowe” dając czytelnikowi dodatkową możliwość zrozumienia ich, przez co tekst staje się otwarty na wiele sposobów interpretacji. Dzięki tak skonstruowanym tekstom czytelnik zostaje skonfrontowany $\mathrm{z}$ odmiennością i podejmuje próbę innego spojrzenia na nie, co jest możliwe poprzez porzucenie przez niego przyzwyczajeń i otwarcie się na poszukiwanie innych metod dekodowania (Gross, 1994: 67). Sposób podwójnego podawania informacji, o którym pisze Sabine Gross, może zarówno wspierać zrozumienie utworu literackiego, wiersza jak również je utrudniać. Obraz jaki przedstawia sobą kompozycja słów może zostać znacznie szybciej rozpoznany, na przeczytanie tekstu potrzeba znacznie więcej czasu. Samo rozpoznanie wizualnej formy graficznej zależy od jasności jej przedstawienia i tego, na ile jest ona zrozumiała. Utwór może posiadać /sygnalizować sens już przed przystąpieniem czytelnika do czytania, rozpoznany obraz może budować swego rodzaju ramę, w którą wpisuje się tekst, ułatwiając jego zrozumienie, warunkiem jest jednak, że tekst i obraz pozostają we wzajemnej relacji.

Forma tekstu oraz jego estetyczna recepcja, sterują aktywnością czytelnika w procesie czytania, odsłaniają struktury, w granicach których rozwija się subiektywny odbiór tekstu przez czytelnika (Krusche, 1985: 186). Jednak nawet w przypadkach, gdy przedstawiony obraz graficzny jest bez większych trudności rozpoznawalny może on wpłynąć na spowolnienie procesu czytania tekstu. Czytelnik musi przestawić się na innego rodzaju odbiór tekstu. Musi zaprzestać czytania aby przekserować uwagę na płaszczyznę tekstu (Gross, 1994: 74-75). Oko czytelnika musi zostać przekierowane na inny rodzaj odbioru, który pozwoli ,przeczytać” graficzną formę tekstu. Ciekawym przykładem jest „Apfel” Reinharda Döhla (Gross, 1994: 78). Forma jakoby przedziera się przez tekst wręcz mimo słów, nie da się określić, gdzie jest koniec, a gdzie początek. Słowa są na pierwszy rzut oka tłem dla przedstawionego kształtu, jednak nie da się on jednoznacznie zidentyfikować bez odwołania do znaczenia słów. Kształt zbliżony do koła, jaki przedstawia sobą grafika nie odzwierciedla wiernie jabłka. Dopiero po lekturze tekstu można ją jako takie zaklasyfikować. Czytelnik, stosujący różne metody czytania, od tradycyjnego czyta- 
nia poziomego, przez czytanie „po okręgu” do czytania z góry na dół, zauważa prawidłowości które determinują grafikę, układ liter względem siebie. Umiejscowiony celowo mniej więcej w 2/3 tekstu od góry „Wurm” (,robak”) zostaje zauważony przeważnie dopiero $\mathrm{w}$ momencie, gdy czytelnik w zasadzie przestaje już czyta, dając efekt zaskoczenia i rozbawienia. W utworach takich jak „Apfel” Döhla forma da się stosunkowo szybko określić dzięki samej sobie lub poprzez tekst. Tekst i obraz graficzny zlewają się w jedną całość, nawet jeśli ich recepcja (czytanie i rozpoznawanie obrazu) odbywa się alternatywnie lub jedna po drugiej.

Ciekawym przykładem jest „womanpoem” Michaela Josepha Philipsa. Obraz graficzny nie jest w tym przypadku jednoznaczny i nie ułatwia zrozumienia poprzez szybkie rozszyfrowanie swojej formy. Również próba samego czytania nie przynosi szybkiego rozwiązania zagadki. Słowa zdają się być ułożone w liniach jednak przerwy i luki między mini znacznie zakłócają proces czytania i rozumienia. Dopiero ponowna próba rozpoznania przestrzennej kompozycji tekstu $\mathrm{w}$ połączeniu $\mathrm{z}$ odkrywaniem określeń części ciała stwarza ramę, w którą wpisuje się cały utwór.

Gross definiuje estetyczne doświadczenie przy recepcji Poezji Konkretnej jako specyficzne powiązanie pomiędzy trybami czytania - w trybie najbardziej elementarnym mamy do czynienia z „reduplikacja sygnifikantów” (,,Reduplikation der Signifikanten", Gross, 1994, s. 74), aż po przykłady wielokrotnej zmiany pomiędzy „czytaniem tekstowym” (,Textlesen”) oraz „czytaniem obrazowym” (,Bildlesen”), czego przykładem jest wspomniany powyżej „womenpoem” M.J. Philipsa (Gross, s. $81-87$, zob. też Denka, s. 185)

Także tutaj przetworzenie informacji regulowane jest przez swego rodzaju układ między tekstem a jego czytelnikami, stwarza on szanse na zrozumienie i apeluje do ich skłonności do poszukiwania sensu. Jeśli tekst wydaje się zbyt niejasny i prowadzi do sprzeczności czytelnik/-czka poszukuje innego rozwiązania. Sama składnia oraz informacje leksykalnie nie tworzą w tym przypadku odpowiedniego sensu. Ich podrzędne zdeterminowanie (Unterdetermination) skłania czasowo sfrustrowanych czytelników/-czki do poszukiwania dodatkowych czynników nadających sens aranżacji (Gross, 2004: 85).

Poezja konkretna działa więc na czytelnika nie tylko słowem, lecz również obrazem graficznym, jaki tworzy swoją treścią, a także rymem i rytmem. Łączy tym samym literaturę z elementami sztuki (plastyki, muzyki) czego dowodem są przedstawione przykłady kompozycji wizualnych, w których forma wpływa na treść a treść na formę determinując się wzajemnie.

\section{Tło historyczne, czyli początki poezji konkretnej}

Poezja konkretna jest nurtem współczesnej poezji, której przedstawiciele eksperymentują niejako z językiem i koncentruje swoją uwagę na wizualnej i akustycznej stronie tekstu. Dostrzegają oni materialność słów i znaków, które odgrywają (nie- 
kiedy) większą rolę niż zawarte w tekście odniesienia do świata zewnętrznego. Materialny budulec językowy w postaci (auto)znaków i słów użytych w tekstach pozostaje we wzajemnej relacji a sens rodzi się z wzajemnych odniesień tych elementów względem siebie (na płaszczyźnie). (Głowiński i in., 2002: 404). Układ znaków odgrywa istotną rolę jeśli chodzi o zjawisko autokomunikacji tekstu poetyckiego, zachodzące w tekstach poezji konkretnej. Polega ono na braku odniesień zewnętrznych. System językowy należy traktować zdaniem poezji konkretnej nie tylko jako system znaków posiadających nadane już znaczenie, ale będących przede wszystkim znakiem ze swoja wizualnością, przestrzennością oraz koncentracja na samym sobie. (Gazda, 2012: 550).

Według Steinbacha i Reichartza, na których powołuje się Krechel, pod pojęciem poezji konkretnej rozumiane są produkty eksperymentowania z językiem większej grupy autorów lat 50 -tych do wczesnych lat 70 -tych. Autorzy ci podejmowali próby przełamania dotychczasowych form poezji oraz stosowanych do tej pory szablonów. Środkiem poetyckim jest niejako zerwanie ze wcześniejszym sposobem komunikacji (Krechel, 1991: 12). Jednym z głównych animatorów poezji konkretnej jest Eugen Gomringer oraz członkowie założonej w roku 1952 w Brazylii grupy „Noinadres”, bracia Augusto de Campos i Haroldo de Campos oraz Decio Pignatari (Gazda, 2012: 550). Praca tej grupy koncentrowała się na poezji, która włączałaby do języka dźwięki i kolory. We wczesnych utworach widoczny jest wpływ kontaktów ze współczesną awangardą muzyczną, której przedstawicielami byli Karlheinz Stockhausen i Pierre Boulez (Krechel, 1991: 10). Wpływ muzyki widoczny jest między innymi w „Dias, Dias, Dias” Augusto de Campos.

Wyżej wspomniana cecha poezji konkretnej, polegająca na koncentracji na samej sobie jest również charakterystyczna dla muzyki konkretnej oraz malarstwa konkretnego, także ich celem nie jest wierne odzwierciedlanie rzeczywistości, lecz forma autotematyzmu. Tym samym metody poezji konkretnej wiążą się ściśle z jej przedmiotem oraz materiałem, $\mathrm{z}$ którego powstaje: $\mathrm{z}$ językiem, ze słowem oraz samą literą (w ich wizualnej i akustycznej postaci). W malarstwie konkretnym odrzucenie wiernego naśladownictwo natury przejawiało się stosowaniem głównie form geometrycznych i elementów sztuki abstrakcyjnej.

W latach 50-tych w krajach niemieckojęzycznych eksperymentują z językiem tworząc poezję konkretną między innymi Eugen Gomringer, Gerard Rühm, C.H. Artmann, Ernst Jandl. Większość z nich to tzw. Wiener Schule. W czasach po II wojnie światowej, a była to reakcja na ideologiczne uwikłanie języka czasach narodowego socjalizmu, pewne kręgi twórców postawiły diagnozę, że język w przestrzeni publicznej jest w pewnym stopniu „wyniszczony”, „zużyty”, stąd też podejmowano próby odkrywania go na nowo, aranżowania własnych spotkań z językiem, doświadczania go w inny, nowy sposób, który byłby krytyczny i kreatywny zarazem. Takie spojrzenie na język miało dawać szanse na jego odnowienie (regenerację) (Krechel, 1991: 14). Poezja konkretna rozwijająca się początkowo w krajach 
niemieckojęzycznych rozprzestrzeniła się w latach sześćdziesiątych XX wieku osiągając zasięg światowy. Nurt ten rozwijał się również w wielu innych państwach, między innymi w Anglii, gdzie z poezją konkretną eksperymentowali I.H. Finley, D.S. Houédard, E. Morgan, S. Bann oraz I. Furnival, w Brazylii i Hiszpanii, gdzie obok członków „Noigandres” tworzyli również R. Azevedo, L.A.Pinto, O. Fahlström, F. Boso, I.G. de Liano oraz F. Millánoraz; w Czechosłowacji z takimi przedstawicielami jak: J. Hiršal, B.Grögerová, J. Kolař i J. Valoch (Gazda, 2012: 550). Ponadto na uwagę zasługuje również twórczość Maurizio Nanucciwe we Włoszech oraz Emmeta Williamsa w USA i Pierre Garniera we Francji (Krechel, 1991: 15). Pod koniec lat sześćdziesiątych nurcie poezji konkretnej rozpoczynają swoją twórczość w Polsce Stanisław Dróżdż, Marianna Bocian i Roman Gorzelski, M. Grześczak, L. Szaruga (Głowiński i in., 2002: 404). Nurt ten jednak nie nabrał u nas większego znaczenia i ma zdaniem Gazdy charakter zdecydowanie marginalny (Gazda, 2012: 550).

\section{Poezja konkretna i estetyka na zajęciach z języka obcego}

Jedną z wartości poezji konkretnej są jej walory estetyczne. Jak twierdzi Harald Weinrich, na którego powołuje się Krechel, utwory poezji konkretnej zbliżają do siebie estetykę i dydaktykę, co uzasadnia wykorzystanie ich na zajęciach do celów wychodzących poza przekazywanie wiedzy o krajach niemieckiego obszaru językowego, bez ograniczania się jedynie do funkcji motywującej.

Dydaktyka nie powinna obawiać się wplatania elementów estetyki w tok zajęć, wierne odzwierciedlanie rzeczywistości czasem tylko pozornie wspiera zajęcia językowe. Dogmat codzienności i realizmu, który koncentruje tematy wokół codziennych sytuacji wzbogacony o elementy estetyczne może wspomóc zdobywanie kompetencji odpowiedzialnej za odnalezienie się w obcej kulturze (Krechel, 1991: 71). Rolę zmysłowego i emocjonalnego doświadczenia w przebiegu procesów socjalizacyjnych oraz jednocześnie brak odpowiednich bodźców estetycznych na zajęciach z języka obcego podkreśla cytowany przez Krechela Barkowski, dlatego ważne jest aby podręczniki zawierały odpowiednie bodźce. Uczenie się języka obcego wewnątrz obcego społeczeństwa jest poniekąd powiązane $\mathrm{z}$ procesem socjalizacji. A procesy socjalizacyjne nie „odbywają się” tylko i wyłącznie przez rozum, lecz również przez zmysły i emocjonalne doświadczenia. Tym samym zajęcia z języka obcego powinny pobudzać zmysły uczących się. Zadanie to powinny spełniać przede wszystkim teksty i ćwiczenia zawarte w podręczniku. Poezję konkretną wykorzystać można z powodzeniem już na niższych poziomach.

Nad wykorzystaniem tekstów poezji konkretnej na zajęciach z języka obcego zastanawia się również Bredella. Jednak stawia on również pytanie: Czy nie mają one zbyt wielu cech sprzeciwiających się raczej ich wykorzystaniu? Wiedza 
„o” tekstach literackich, która tym samych przekazywana jest na takich zajęciach, nie przyczynia się do rozwiązywania codziennych zadań, a do tego uczeń ma zostać przygotowany przede wszystkim, to ta umiejętność ma zostać przez niego opanowana (Bredella, 1984: 353). Poza tym tradycyjne metody nie zwracają raczej uwagi na doświadczenia czytelnicze ucznia, lecz na sam tekst. Ograniczenie do samego tekstu, traktowanego jako rodzaj ,pojemnika ze znaczeniami” jest niewystarczające, na co wskazuje "responce theory” (Bredella, 1984: 354-355). Próby wyjaśnień tekstu często są dla uczniów zbyt trudne i przekraczają ich możliwości. Wymóg „czystego” streszczenia tekstu rygorystycznie ignoruje subiektywne doświadczenia czytelnicze i zsuwa je na dalszy plan. Uwzględnienie doświadczenia czytelniczego uczniów w pracy z tekstem mogłoby pozytywnie wpłynąc na ich motywacje do pracy i zaangażowanie w wykonywanie zadań. Reakcja uczniów na tekst powinna być wysunięta na pierwszy plan.

Patrząc na konstrukcję poezji konkretnej i środki, jakie wykorzystane zostały przy jej tworzeniu, trudno zaakceptować stwierdzenie, że tylko stosowanie prostych środków językowych pozwala na tworzenie prostych wypowiedzi (mniej wymagających pod względem formy i treści). Proste środki językowe - jak się okazuje - mogą służyć również do przekazania ambitniejszych wypowiedzi.

Utwory poezji konkretnej wykorzystywane na zajęciach z języka obcego rozwijają wrażliwość estetyczną u dzieci, młodzieży czy osób dorosłych, kształtują rozwój intelektualny i umiejętności językowe. Obraz graficzny, podlegający jako forma recepcji, jest swego rodzaju wskazówką do interpretacji, jeśli tylko sięga się do osobistych doświadczeń odbiorcy jak również do otaczającego go świata. Próbując zrozumieć treść i przesłanie utworu odbiorca stara się „odczytać” jego abstrakcyjne elementy nadając im konkretne znaczenie.

Krechel (1991: 10) podkreśla potrzebę zwrócenia uwagi na kulturalno-historyczny i polityczny kontekst utworu poezji konkretnej celem pełniejszego zrozumienia informacji krajoznawczych i kulturowych, jakie ona ze sobą niesie. Wsparcie tego rodzaju zależne miałoby być od samego adresata, poziomu jego znajomości językowych oraz zainteresowań. Również Krusche (1991: 184-187) mówi o zwróceniu uwagi na to, iż wybrane teksty powinny zawierać swego rodzaju punkt odniesienia, powinny odzwierciedlać stosunek indywiduum do ustrukturyzowanego świata, który go otacza i w którym się odnajduje. Trudne w tym kontekście okazują się być detale historyczne czy kulturowe, szczególnie jeśli uczący się pochodzą z innego kręgu kulturowego. W takim przypadku znacznie łatwiej przekazać treści abstrakcyjne niż absolutnie nieznane i odlegle fakty i realia.

Koncentracja na odbiorcy i jego możliwościach zrozumienia tekstu ma swoje początki już w latach 80-tych poprzedniego stulecia (Paradigmawechsel) (Kast, 1984). Odbiorca ze swojej strony powinien odważyć się zareagować odpowiednio na tekst oraz wykorzystać swoje wcześniejsze doświadczenia (zarówno życiowe jak i czytelnicze). Mogą mu w tym pomóc opisane przez Kruschego referencje, wśród 
których wyróżnia: obrazowość (Anschaulichkeit), historie w kontekście historii świata; język jako system, autoreferencję tekstu, rekurencję (Selbstreferenz im Text, Rekurrenzen), groteskę językowa (Krusche, 1985: 188-203). Obrazowość, opisana przez Kruschego na podstawie tekstu „Apfel” Reinharda Döhla, jak sama nazwa tej cechy wskazuje, opiera się na wizualnym rozpoznaniu kompozycji stworzonej przez słowa. Istotne jest, aby czytelnik posiadał własne doświadczenia, które pomogą mu poprawnie rozpoznać przedstawiony kształt. „Apfel” Döhla znakomicie nadaje się do pracy na zajęciach jako jeden z pierwszych tekstów w ogóle, dając możliwość zdobycia przez uczniów doświadczenia nawiązującego do sposobu czytania i nauki. Proces dekodowania znaczenia w oparciu o wizualność pozwala odkrywać język obcy bez korzystania ze słownika czy podręcznika z gramatyką. Na zajęcia z języka obcego proponowany jest też tekst Timma Ulrichsa „Ebbe”.

Kolejnym schematem referencyjnym jest wedhug Kruschego historia w rozumieniu historii świata. Tylko znane nawet odległym kulturom fakty i daty stwarzają ramę, w która może wpisać się interpretacja tekstu. Do przytoczonych przez Kruschego przykładów należą „Markierung einer Wende” Ernsta Jandla oraz „lehrreich” Buckharda Garbe. Krusche wyróżnia również teksty, które bazują na języku jako na systemie i już na pierwszy rzut oka przypominają schematy odmiany czy to rzeczowników (Ernst Jandl „Der Tod”) czy też czasowników (Rudolf Steinmetz „Konjugation”). Kolejną grupą są według Kruschego teksty odwołujące się do samych siebie, narzucające swą formą pewną kontynuację (Ernst Jandl "fünftersein”, Kurt Marti „Umgamgsformen”, Rudolf Otto Wiemer „unbestimmte Zahlwörter” oraz „Zeitsätze”).

Wyżej wymienione zalety, cechy poezji konkretnej oraz obszary, do których się ona odwołuje zdają się udowadniać celowość jej wykorzystania na zajęciach, z drugiej jednak strony nasuwa się pytanie czy poezja konkretna nie obarcza jednak dodatkowo swoją „obcością” ucznia, który boryka się już z nowym obcym językiem oraz nową obcą kulturą? Czy celem zajęć z języka obcego nie jest raczej redukcja „obcości”? przybliżanie nowej kultury i nauka nowego języka? Czy poezja konkretna jako sztucznie stworzona niekonwencjonalna forma może być zatem stosowana jako środek dydaktyczny?

Krechel zwraca uwagę na to, że teksty te nie utrudniają bezpośrednio „leksykalnego" rozumienia za to przyczyniają się do powstania wieloznaczności, a ona z kolei umożliwia spojrzenie z wielu perspektyw, co stwarza wiele możliwości wykorzystania.

\section{Funkcje i cele pracy z poezją konkretną na lekcji}

Poezja konkretna może być z powodzeniem stosowana na lekcjach języka obcego. Chcąc do niej sięgnąć, nauczyciel powinien zastanowić się jednak nad celem dydaktycznym, jaki zamierza osiągnąć. Poezja konkretna może przyczynić się do 
redukcji strachu ucznia wynikającego z konfrontacji z obcym językiem, może przyczyniać się do jego otwarcia się na nowy język i nowe sytuacje. Prosty język charakteryzujący się tendencją redukcji ułatwia recepcję dzieła literackiego, problemy stwarzać może jednak otwartość tekstu (textuelle Offenheit) oraz brak kontekstu. Sam fakt eksperymentowania autorów z językiem, przełamywania norm i logiki, zachęca uczniów do ich naśladowania, rozpoczynając zabawę z językiem przestają się go bać (Krechel, 1991: 60)

Podczas pracy z poezją konkretną uczeń poznaje nowe techniki czytania i uczy się je stosować. Są to techniki wymagające aktywnego i produktywnego „obchodzenia się z tekstem". Uczeń poznaje specyficzny sposób czytania (relacje między pojedynczymi/ poszczególnymi miejscami w tekście muszą zostać dopiero odkryte) - odbiorca spogląda na tekst w sposób krytyczny i zdystansowany (Krechel, 1991: 82-99).

Konkretne teksty dzięki swojej otwartości oraz brakującemu kontekstowi zapraszają niejako czytelnika do zabawy z nimi, do wypełniania niedopowiedzianych treści. Stwarza to możliwość wniesienia własnych doświadczeń uczniów, zwiększa ich aktywność dzięki temu, że nie muszą się oni identyfikować z przykładami przedstawionymi w podręczniku (Wierlacher, 1980: 319; Hunfeld, 1980: 514; por. też Krechel, 191: 87). Równolegle stwarza to również okazję do wspierania/ rozwijania kompetencji narracyjnej. Luki wypełnione zostają przez czytelnika pod względem semantycznym, czego rezultatem jest przekształcanie poezji konkretnej w różnorodne teksty komunikacyjne i narracyjne. Każdy uczeń może zmienić tekst bazowy w indywidualny sposób, co daje podczas zajęć z języka obcego możliwość porównania powstałych tekstów w grupie. Brakujący kontekst daje okazję do dyskusji. Sprzyja to również rozwijaniu zdolności do interpretacji tekstu, to właśnie własne doświadczenia wypełnienia przez ucznia (na zasadzie skojarzeń) niedopowiedzeń jakie niesie ze sobą tekst. $\mathrm{W}$ grupach etnicznie mieszanych, skupiających uczniów z różnych krajów, dodatkową zaletą jest możliwość wspierania kompetencji interkulturowej.

Utwory, poprzez zapraszanie do zabawy, mogą wspierać próby własnej twórczości językowej oraz próby posługiwania się językiem, mogą nakłaniać do refleksji nad nim, jego użytkowaniem, jak również do refleksji na tematy polityczne i problemy społeczne rozszerzając słownictwo i wspierając kompetencje językowe.

Poezja konkretna może pojawić się na zajęciach z języka obcego również przy okazji lekcji gramatycznych ze względu na koncentrację na strukturach, regułach obowiązujących wewnątrz danego języka, na formie (przykład E. Jandl „Der Tod”). Uwidocznione struktury gramatyczne mogą służyć wprowadzeniu nowego materiału, jego utrwaleniu bądź wskazaniu odstępstw od reguł. Pozostając w kręgu reguł, tym razem fonetycznych, warto wskazać kolejną możliwość jaką oferują utwory poezji konkretnej jaką jest ćwiczenie prawidłowej wymowy (Krechel. 1991: 82-99). Przykładem jest wiersz Ernsta Jandla „Ottos Mops“ (Jandl, 1970: 58).

Poezja konkretna, wykorzystana na zajęciach, może służyć wspieraniu motywacji uczących się oraz urozmaicić lekcje. Jeśli wiersze, kompozycje słów zainteresują 
ucznia którąkolwiek z płaszczyzn, jakie oferują, czy to od strony graficznej, akustycznej, samą formą, swym tematem lub luką interpretacyjną, niedopowiedzeniem, angażuje się on bardziej w pracę, podnosi się jego motywacja i kreatywność językowa.

\section{Przykłady z podręczników do języka niemieckiego}

Podręczniki korzystają z zalet poezji konkretnej: język przedstawiany jest w zabawny sposób który redukuje bariery językowe; o takich tekstach da się łatwiej mówić. Uczniowie widzą, że słowa (czy zdania) można: przekształcić, można zmienić ich znaczenie.

Poezja konkretna w sposób realny i uchwytny przedstawia obcą rzeczywistość. Nic w niej nie musi być zniekształcone, uproszczone czy dopasowane do niskiego poziomu znajomości językowych. Zrozumienie treści ułatwione jest dzięki wizualizacji (znaczenie ewentualnie nieznanego słownictwa może zostać rozszyfrowane). Dużą role odgrywa sama czcionka i wygląd liter, które dostarczają wskazówek naprowadzających na znaczenie poszczególnych słów. Słowa mogą zostać w taki sposób umieszczone na płaszczyźnie aby odzwierciedlały własne znaczenie, można z nich konstruować przedmioty. Powyżej przedstawione przykłady mogą być zachętą do samodzielnego komponowanie poezji konkretnej przez uczniów.

W podręcznikach do nauki języka obcego znaleźć można wiele przykładów poezji konkretnej. W podręczniku „Deutschaktivneu 1A“ (Neuer, Scherling, Schmidt, 1987: 56) zamieszczony został między innymi wiersz „Empfindungswörter“ Rudolfa Otto Wiemera, którego dydaktyzacja przedstawiona została poniżej, w rozdziale piątym podręcznika znajdują się dwa utwory Ernsta Jandla „Fünftersein“ (pojawiający się również w Stufeninternational 2 oraz Moment mal 1) oraz „Markierungeiner Wende“ (również w „Stufeninternational 3") jak również wiersz Burckharda Garbe „Lehrreich“. Kolejne rozdziały proponują utwory Rudolfa Otto Wiemera „unbestimmte Zahlwörter“ (Neuer, Scherling, Schmidt, 1987: 85) oraz „Possessivpronomen“ (Neuer, Scherling, Schmidt, 1987: 115). W kolejnych częściach podręcznika „Deutschaktivneu“ dla poziomu 1B zaproponowane zostały wiersze: „Zeitsätze“ Rudolf Otto Wiemer, „Erziehung” UweTimm oraz „Familienfoto” Ernsta Jandla w podręczniku dla poziomu 1C. Podręcznik „Moment mal“ część 1 proponuje poezję konkretną najczęściej w części pracy ze słownictwem lub do ćwiczenia wymowy. W dziale siódmym „Farben, Häuser, Landschaft“ wykorzystano możliwość wizualizacji znaczenia wyrazów. Litery tworzące wyraz zostały ustawione w sposób symbolizujący jego znaczenie (ideogram). Zadaniem uczniów jest odnalezienie słów oraz ich znaczeń. Symboliczny układ liter, osadzony dodatkowo w kontekście tematu zajęć, maluje niejako przed oczami ucznia obrazy, przekazując nie tylko znaczenie zapisanych słów ale wskazuje również na jedną ze strategii uczenia się słownictwa. Kompozycja pierwsza przedstawia ulicę prowadzącą przez miasto (Stadt - 
miasto; Straße - ulica). Kompozycja druga przedstawia elementy krajobrazu, wzgórza oraz rosnące na nich drzewo (hügel - wzgórze; baum - drzewo). Kolejne symbolizują dom (Haus) oraz plac (Platz). W podręcznikach „Moment mal“ znaleźć można między innymi również takie utwory poezji konkretnej jak „Fünftersein” Ernsta Jandla, „Ping pong” Eugena Gomringera, oraz „Spuren im Sand” Hansa Baumanna.

Podsumowując można stwierdzić, że podręczniki zawierają przykłady poezji konkretnej. Przykłady dział znaleźć można zarówno w części pracy ze słownictwem, w części gramatycznej (prezentacja lub utrwalenie reguł) oraz w części poświęconej ćwiczeniu wymowy co potwierdza różnorodny sposób wykorzystania wartości, jakie oferuje poezja konkretna nie pomijając jej wartości krajo- i kulturoznawczej.

Analizując ćwiczenia nawiązujące do proponowanych utworów, a raczej ich brak, należałoby zastanowić się czy uczeń i nauczyciel nie zostają pozostawieni bez potrzebnego wsparcia.

\section{Przykłady dydaktyzacji i scenariuszy zajęć z wykorzystaniem tekstów poezji konkretnej}

\subsection{Przykład wykorzystania wiersza „Empfindungswörter” według Krechela}

„Empfindungswörter” Rudolf Otto Wiemer

Aha die Deutschen

Ei die Deutschen

Hurra die Deutschen

Pfui die Deutschen

Ach die Deutschen

Nanu die Deutschen

Oho die Deutschen

Hm die Deutschen

Nein die Deutschen

Jaja die Deutschen

Tekst przytoczonego powyżej utworu składa się w większości z wykrzykników, od których rozpoczyna się każda linijka. Wykrzykniki jako nieodmienne części mowy wyrażają m.in. silne stany emocjonalne, uczucia. Krechel przed przystąpieniem do pracy z tym wierszem porównał wykrzykniki w języku niemieckim z wykrzyknikami w innych językach. Okazało się, że istnieje wiele podobieństw tym samym zdecydował się on na prezentację tekstu bez wcześniejszych wyjaśnień. Cały zestaw zaoferowanych reakcji emocjonalnych, prezentowanych bez kontekstu, w połączeniu z ograniczeniem tematu do samych „Niemców” jest okazją do wyrażenia 
przez ucznia swoich uczuć i swojego nastawienia względem Niemców oraz do opowiedzenia o swoich doświadczeniach z nimi. Wiersz może być okazją do nazwania poszczególnych emocji w języku obcym. Jako możliwe cele pracy $\mathrm{z}$ utworem „Empfindungswörter” Krechel podaje:

1. Poznanie znaczenia i funkcji niemieckich wykrzykników

2. Praca ze słownictwem (zakres tematyczny: uczucia, emocje)

3. Ćwiczenie argumentowania poprzez wyjaśnianie, uzasadnianie, obronę własnego punktu widzenia (gramatyczne zastosowanie: weil, da, denn, deshalb, wegen)

4. Refleksja na temat własnego nastawienia uczniów do Niemców i Niemiec (w jakich sytuacjach myślą o nich pozytywnie, a w jakich negatywnie)

Krechel proponuje pracę $\mathrm{z}$ tekstem $\mathrm{w}$ grupie na niższym poziomie ( 7 tydzień kursu intensywnego dla obcokrajowców w Niemczech). Celem tych zajęć jest rozumienie i prawidłowe stosowanie wykrzykników niemieckich oraz refleksja na temat własnego nastawienia względem Niemców i Niemiec. Proponowany przez Krechela przebieg zajęć rozpoczyna się od podania przez nauczyciela tytułu wiersza i postawienia pytania o to, czego uczniowie się spodziewają (pytanie o możliwą treść). Tym samym uczniowie maja możliwość nawiązania do swojej wiedzy oraz doświadczeń. Podane przez nich odpowiedzi zbierają informacje historyczne a także poruszają temat mentalności, charakteru oraz tradycji. Dopiero teraz, po ówczesnym przygotowaniu do jego odbioru, rozdany zostaje tekst wiersza. Po lekturze tekstu uczniowie rozmawiają w parach o swoim pierwszym wrażeniu.

Na zajęciach, które opisuje Krechel, uczniowie, mimo starań nauczyciela, nie powiedzieli dużo i mieli problemy z uzasadnieniem wypowiedzi. Trudności te wynikały z brakujących możliwości językowych. Utwór ten został wykorzystany do pracy z uczniami o niższym poziomie językowym, a jego wybór uzasadniać miała prosta konstrukcja.

Opisany powyżej tekst zaproponowany został również do wykorzystania na zajęciach przez Neunera w podręczniku DeutschaktivneuA1 (Neuer, Scherling, Schmidt, 1987: 56). Do wiersza nie są jednak zaproponowane żadne ćwiczenia. Obok tekstu widnieje jedynie 8 obrazków, które dają możliwość przyporządkowania do poszczególnych wersów, praca musi być w tym wypadku skoncentrowana na wyjaśnieniu znaczenia słówek-wykrzykników (Empfindungswörter). Cały sukces wynikający $\mathrm{z}$ wykorzystania zaproponowanego tekstu zależy zatem od kreatywności nauczyciela.

\subsection{Przykład wykorzystania wiersza „Worte”, autor nieznany, według propozycji Webera}

„Worte” nieznanego autora (Weber, 1995: 25), to dwie kompozycje skonstruowane z powieleń słowa „Worte"(słowa), będącego również tytułem, oraz zaimków osobowych „ich” (ja) i „du”(ty). Weber zwraca uwagę na rolę znaczenia użytego 
w kompozycji słowa. Słowa mają moc. Mogą niszczyć ale mogą też budować i rozwijać więzi międzyludzkie. Język może ludzi dzielić, może również ich łączyć, co uwidaczniają obydwie kompozycje graficzne w postaci muru oraz mostu. Pytaniem wyjściowym jest czy uczniowie są w stanie rozpoznać te obrazy? Czy rozumieją przenośnie, czy mają odpowiednie doświadczenie życiowe? Autor wiersza „zbudował” w pierwszej kompozycji mur ze słów („Worte”) który stoi pomiędzy dwoma osobami, pomiędzy ,ich” a „du”. W drugim obrazie słowa łączą dwie osoby budując most. Tym samym przedstawione są dwie sytuacje: pierwsza, w której jedna osoba zraniła drugą oraz druga sytuacja symbolizująca przeprosiny oraz szukanie porozumienia. Weber proponuje, aby uczniowie wymyślili historię, jak doszło do obydwu sytuacji i je opisali. Jedną z możliwości jest forma opowiadania, druga formą dialogu między „ich” a „du”. Weber podkreśla też możliwość odniesienia przenośni „muru” i „mostu” do tematów z życia codziennego, polityki, stosunków międzynarodowych oraz do dyskusji na temat przesądów i nieporozumień. Sytuacja na zajęciach z języka obcego jest kolejną możliwością. Nieznane w początkowej fazie nauki słowa budują barierę, która z czasem, gdy uczeń poznaje coraz więcej słów przeobraża się w pomost.

Czy przeciętny uczeń przygotowany jest w dostatecznym stopniu do estetycznego odbioru poezji? Na to pytanie trudno jednoznacznie odpowiedzieć. Zdawałoby się, że ma odpowiednie doświadczenie wynikające chociażby z ciągłej konfrontacji z hipertekstami multimedialnymi. Wszystko zależy jednak od jego indywidualnych doświadczeń a przede wszystkich wrażliwości artystyczno- estetycznej oraz zaoferowanego mu wsparcia ze strony nauczyciela. Czy uczeń będzie potrafił odpowiednio powiązać element werbalny i graficzny czy akustyczny? W latach 90-tych bardziej niż obecnie doceniano poezję konkretną - może warto by do niej wrócić w kontekście nauczania przez literaturę?

\section{Bibliografia}

Barkowski, H. i M. Fritsche. 1980. Deutsch für ausländische Arbeiter. Gutachten zu ausgewählten Lehrwerken. Königsstein/Ts.: Verlag Manfred Werkmeister.

Bredella, L. 1984. „Literarische Texte im Fremdsprachenunterricht: Gründe und Methoden“. W zbiorze:

Heid, M. (red.). Literarische Texte im kommunikativen Fremdsprachenunterricht. Beiträge eines

Werkstattgespräches des Goethe House New York vom September 1984. München: Goethe Institut. 352-394.

Denka, A. 2000. „Beschreibung fremdsprachlicher literarischer Leseprozesse am Beispiel der Konkreten Poesie“. Studia Germanica Posnaniensia 26. 183-197.

Gazda, G. 2012. Stownik rodzajów i gatunków literackich. Warszawa: PWN.

Głowiński, M., Kostkiewiczowa, T., Okopień-Sławińska, A. i J. Sławiński. 2002. Słownik terminów literackich. Wrocław: Ossolineum.

Gołaszewska, M. 1984. Zarys estetyki. Problematyka, metody, teorie. Warszawa: PWN.

Gomringer, E. (red.). 2009. Konkrete Poesie. Stuttgart: Philipp reclam jun. 
Gross, S. 1994. Lesezeichen. Kognition, Medium und Materialität im Leseprozess. Darmstadt: Wissenschaftliche Buchgesellschaft.

Jauss, H.R. 1999. Historia literatury jako prowokacja. Warszawa: Wydawnictwo IBL.

Kaniewska, B. i A. Legeżyńska. 2003. Teoria literatury. Skrypt dla studentów filologii polskiej. Poznań: Wydawnictwo „Poznańskie Studia Polonistyczne”.

Karolak, Cz. 2011. Dydaktyka literatury wobec potrzeb nauki języka w warunkach obcokulturowych. Poznań: Wydawnictwo Naukowe UAM.

Kast, B. 1984. Literatur im Unterricht. Methodisch-didaktische Vorschläge für den Lehrer. München: Goethe - Institut.

Krechel, R. 1991. Konkrete Poesie im Unterricht des Deutschen als Fremdsprache. Heidelberg: Julius Gross Verlag.

Krusche, D. 1985. „Die Chance des fremdkulturellen Lesers. Konkrete Poesie im Anfangsunterricht Deutsch als Fremdsprache und danach?“. W: Krusche, D. Literatur und Fremde: zur Hermeneutik kulturräumlicher Distanz. München: Iudicium Verlag. 184-208.

Neuner, G., Scheling, T. i R. Schmidt. 1987. Deutsch Aktiv Neu: Lehrbuch 1A. Berlin: Langenscheidt.

Weber, H. 1995. Vorschläge 2: Literarische Texte für den Unterricht DaF. Bonn: Inter Nationes.

Wicke, R.E. 2004. Aktiv und kreativ lernen: Projektorientierte Spracharbeit im Unterricht. Deutsch als Fremdspreche. München: Max Hueber Verlag, 